\title{
Tracking SMME research in South Africa's PRIORITY SECTORS
}

\author{
Christian M Rogerson
}

School of Geography, Archaeology \& Environmental Studies, University of the Witwatersrand

\begin{abstract}
The National Industrial Policy Framework and the Accelerated and Shared Growth Initiative for South Africa emphasise the importance of promoting select 'priority sectors'. This paper provides a review of existing research concerning SMME development in the three priority sectors of tourism, business process outsourcing and offshoring (BPO \& O) and, creative industries. The paper argues for the importance of undertaking sector-differentiated research on SMME development in South Africa in order to complement other research which is focussed on sector development as a whole.
\end{abstract}

JEL L33, 83

\section{1 Introduction}

The Accelerated and Shared Growth Initiative for South Africa (ASGISA) identifies a group of sectors that represent 'low hanging fruit' which is deemed ripe for development. Priority sectors are viewed as those sectors in which the country "has a range of comparative economic advantages which, if fully exploited, would lend themselves to higher rates of economic growth" (DTI, 2005a). Under the National Industrial Policy Framework ten sectors are listed that are differentiated by the three sub-categories of immediate, top and medium-term priority (DTI, 2006a). Immediate priority sectors are those in which support programmes can be implemented with immediate effect. Top priority sectors are those that are close to implementation, albeit require coordinated government action in order to address constraints to their development, and medium term sectors are those that require sector development efforts that will come to fruition in the medium term (DTI, 2006a: 33).

The objective of this article is to provide a critical review of existing research work and debate concerning SMMEs in South Africa's priority sectors. In the 2006 strategic framework document for the national government's efforts in fostering entrepreneurship and small business promotion, one of the key principles is "the need for sector- or industry-focused programmes" (Upstart Business Strategies, 2006: 70). The central aim here is to emphasize the value and importance of undertaking SMME research in the country's priority sectors through examining the state of existing knowledge across three of the ten priority sectors. The three selected case studies of priority sectors are (1) business process outsourcing and offshoring (BPO \& $\mathrm{O}),(2)$ tourism (the two immediate priority sectors); and, (3) creative industries which is categorised as medium-term priority. The paper unfolds through five sections of material that deal respectively with definitional issues; the current state of research knowledge in $\mathrm{BPO} \& \mathrm{O}$, creative industries, and tourism; and, a concluding discussion.

\section{2}

\section{Defining the scope of the three sectors}

At the outset, it must be recognised that the three selected priority sectors of BPO\&O, tourism and creative industries are extraordinarily diverse in their make-up. Overall, the three sectors share the characteristic that their precise boundaries 
are 'fuzzy' and often disputed as these 'sectors' comprise a range of different activities.

One of the features of the BPO\&O sector, that has emerged globally as a recent new focus for economic development programming, is that it has blurred boundaries (Paladin Consulting, 2003; Kennedy, 2004). The DTI's CSP detailed report admits that "there is still huge debate and controversy about the definition and scope of the processes that should be included in/excluded from the BPO\&O sector" (Paladin Consulting and Consulta Research, 2004: 4). In research undertaken for the Western Cape Micro-Economic Development Strategy, BPO was defined as "the transfer to a third party of groups of tasks and processes, which primarily involve the handling and manipulation of data (taken in its broadest sense to include voice data" (Naidoo \& Neville, 2005: 11). When outsourced processes require voice communication with customers. This is defined as typically done through a call or contact centre, the latter term more generally encompassing both outbound and inbound calls (Naidoo \& Neville, 2005: 11). For McKinsey \& Company (2005: 2) the wider grouping of $\mathrm{BPO} \& \mathrm{O}$ is defined as encompassing "a broad range of service lines, including customer care, human resources services (for example benefits and payroll administration), payment services, finance and accounting, back-office and administration (for example, data entry, claims processing) and high-end offshoring services (for example, engineering, design and analysis)".

Overall, the difficulty of scoping the precise boundaries of BPO\&O is evident from the DTI's Sector Development Strategy, in which eight distinct broad categories or sub-sectors of the BPO\&O are differentiated (DTI, 2005b). These include inter alia: (1) niche functions (including advertising; animation; biotech research; education, training and development; engineering and design; logistics and fulfilment; procurement; professional services; translation and transcription services, and transportation services); (2) IT and technical services (including infrastructure management, IT outsourcing - network management and maintenance; IT outsourcing - software development and maintenance, and network maintenance);
(3) call centre functions (including inbound customer service; inbound help desk; inbound sales; inbound technical support; market research services; outbound data cleaning and data capture; outbound debt collection; outbound customer interviews, research and surveys; outbound telemarketing/sales, and travel and tourism - bookings and reservations); (4) financial accounting and administration; (5) human resource functions; (6) data conversionentry, scanning, administration and maintenance; (7) insurance industry functions; and, (8) website design and development (DTI, 2005b: 12) .

Internationally, the term "creative industries" is also of very recent origin. In common with BPO\&O, however, it is a sector that is currently receiving considerable international policy attention (see New Zealand Trade and Enterprise, 2005 and Australian Government Culture and Recreation, 2006). It is suggested that the formal origins of the concept are to be found in the Creative Industries Task Force (CITF), which was established by the Blair Labour Government after its election in Britain in 1997. The Creative Industries Mapping Document, which was prepared by the newly constituted Department of Culture, Media and Sport (1998: 1), viewed creative industries "as those activities which have their origin in individual creativity, skill and talent and which have the potential for wealth and job creation through generation and exploitation of intellectual property". In common with $\mathrm{BPO} \& \mathrm{O}$, the boundaries of "creative industries" are equally imprecise. The UK CITF identified as many as thirteen different activities that were to be encompassed within the framework of "creative industries".

In South Africa recognition of "creative industries" began with the important series of reports produced on "cultural industries" for the (former) Department of Arts, Culture, Science and Technology by the Cultural Strategy Group (1998a, 1998b, 1998c, 1998d, 1998e). The category of "cultural industries" was defined widely to incorporate music, the visual arts, the publishing sector based on creative writing of literature, the audio-visual and media sector, performing arts, the craft sector (including traditional African art, designer goods and 
souvenirs); cultural tourism, and, the cultural heritage sector. The Cultural Strategy Group (1998a) also included within cultural industries the sectors of design and fashion which were seen as "sectors where creative input is a secondary but critical means of enhancing the value of other products whose marketability and effectiveness would otherwise be lessened". In Gauteng the preparation of the provincial creative industries development framework was informed by a definition of "that bundle of activities where creativity is a prime condition of its existence" (Gauteng Province, 2005: 7).

Research conducted for the Western Cape Provincial Micro-Economic Development Strategy prefers a more "inclusive working definition" of creative industries as:

those areas of social and economic activity that are premised on - or closely allied with - individual or collective intellectual or artistic creativity, innovation and originality and/or the preservation, teaching and celebration of cultural heritage including language and which have the capacity to provide work and generate income for the original creators as well as for others involved in education and training, production, distribution, documentation and support for creative products or cultural experiences. (Van Graan, 2005a: 6).

Of note is that the application of this particular "inclusive" definition results in a different scoping of creative industries to that of the Cultural Strategy Group, and includes, for example, the activities of language schools (see Van Graan, 2005a, 2005b).

The tourism sector together with BPO\&O and creative industries shares the problem of a lack of agreed definition as to its precise boundaries. As pointed out in the 2003 Annual Review of Small Business in South Africa, "in terms of economic analysis, the tourism sector is highly distinctive in that it is not a sector that is formally classified as such in terms of the International SIC" (DTI, 2004a: 67). The United Nations World Tourism Organisation (UNWTO) makes a distinction between the narrow definition of the "travel and tourism industry", which comprises transport, accommodation, catering, entertainment and related activities, and a wider "travel and tourism economy" including all activities that link to or provide services/inputs into the core travel and tourism industry. Conventionally, most tourism analysts today apply the UNWTO narrow definition, albeit often extended to include those direct service suppliers into tourism enterprises. Of significance however, is growing acknowledgment that tourism (like manufacturing) is not an homogenous industry and that various sub-segments of tourism must be unpacked and recognised in terms of policy analysis.

In segmenting the tourism sector, the most basic distinction is that between international, regional and domestic forms of tourism. Other differentiation and segmentation exist in respect to the purpose of tourism with distinctions made between leisure, business, VFR (visiting friends and relatives), health and religious tourism. Finally, segmentation is often undertaken along product lines with, for example, the categories of adventure, backpacker, cultural, eco-, mass, medical, shopping, sports, wine tourism and many others.

\section{3}

\section{BPO\&O - The current state of research}

Although call centres and "back room" office functions began growing significantly in South Africa in the 1990s (Benner, 2006), as late as 2002 there was no available research on the BPO\&O sector in South Africa. The first substantial work was the baseline study provided in 2002 by Mitial Research (2002). In fact, until 2000 the term BPO\&O hardly existed in South African economic debates. Since 2000, however, the potential attractions of the BPO\&O sector for job creation and contribution to GDP in South Africa have been more widely recognised (Benner, 2006; Benner et al., 2007). In addition, BPO\&O was acknowledged as an opportunity "because it has the potential to link formerly unemployed young people into the global economy" (Business Trust, 2007: 22).

By 2006 the research situation had changed to the extent that a series of detailed consultancy reports were available on the sector providing 
the foundation for sectoral initiatives launched by national, provincial (Western Cape, KwaZulu-Natal) and local government (Johannesburg, Cape Town) to support the growth of labour-intensive BPO\&O operations (see Mitial Research, 2002; Paladin Consulting, 2003; Kennedy, 2004; Paladin Consulting and Consulta Research, 2004; DTI, 2005b; McKinsey \& Company, 2005; Naidoo \& Neville, 2005). Nevertheless, it is striking that, apart from Benner's (2004) (unpublished) research which examines the quality of jobs created in South African call centres, almost no independent academic research is available on the sector.

The existing research on the BPO\&O sector essentially focuses on identification of global and domestic market trends, a situational analysis of the South African sector, constraints, challenges, opportunities, value proposition and suggestions for government support interventions (Kennedy, 2004; Paladin Consulting and Consulta Research, 2004; McKinsey \& Company, 2005; Naidoo \& Neville, 2005). Information on industry structure and SMME development is fragmentary (Benner et al., 2007). The DTI's CSP detailed analysis report states that limited information is available on the number and sizes of firms due to the fact that "the South African BPO\&O sector is not classified as an industry" (Paladin Consulting and Consulta Research, 2004: 88). Moreover, "given the diversity of the BPO\&O sector, with the numerous types of service processes that are included in the Niche sector, it is extremely difficult to count the number of SMMEs" so that "there is no comprehensive data list" (Paladin Consulting and Consulta Research, 2004: 89).

Based on a small sample of firms this study observed that "companies that supply the most $\mathrm{BP} \& \mathrm{O}$ services (locally and internationally) employ between 50 and 150 people (40 per cent of sector). The second largest segment of companies supplying BPO\&O services consist of those that employ less than 50 people, i.e. the SMMEs (30 per cent of sector)" (Paladin Consulting and Consulta Research, 2004: 88). From the Western Cape there is further evidence of the participation of SMMEs in both the provision of data-focused services (ie not contact centres) as well as voice-focused services (Naidoo and Neville, 2005). The Western Cape study stresses, however, that "outsourcing is volume business" and that this poses risks for the setting up of new BPO operations, aside from niche activities (Naidoo \& Neville, 2005: 49). Nevertheless, what this fragmentary information discloses is, that whilst the BPO\&O sector undoubtedly is dominated by large vendors, the contribution of SMMEs in the landscape of the BPO\&O sector in South Africa cannot be overlooked.

The core theme discussed in the existing body of BP\&O research is of enhancing sector competitiveness and capabilities as a whole by addressing identified sector constraints. Emphasis is upon addressing country-level weaknesses such as absence of government support, cost and quality of transport facilities, cost of telecommunications infrastructure and, crime/security issues (Paladin Consulting and Consulta Research, 2004: 113). In addition, several weaknesses identified in South African BPO\&O suppliers must be confronted, most importantly of issues relating to workforce capability or skills. A group of interventions are put forward to strengthen and deliver a distinctive South African value proposition in the BPO\&O sector (Kennedy, 2004; McKinsey \& Company, 2005; Naidoo \& Neville, 2005). Among the most significant are the imperative for strategic marketing initiatives, a programme for comprehensive skills development, a favourable regulatory framework and investor support environment, the strengthening of governance and quality assurance within the industry, and the building of programme management capability (Kennedy, 2004; McKinsey \& Company, 2005).

The essential message that runs through the existing research on $\mathrm{BP} \& \mathrm{O}$ is that the implementation by national or sub-national governments of proposed initiatives to strengthen the sector would inevitably have positive knockon effects for SMME development. For example, the McKinsey \& Company (2005: 7) report states that "through focused education and skillsbuilding efforts by a credible industry body, the growth of small and medium enterprises alongside the larger third party vendors would be stimulated". Likewise, in the DTI's (2005b: 
30) Sector Development Strategy an expected outcome of the implementation of strategic initiatives is to be "new business opportunities created for SMMEs, with participation in the sector promoted by developmental funding and support". Overall, in Sector Support programme for BPO\&O the core focus is upon job creation rather than SMME development through building an enabling environment, attracting investment and linking previously marginalised groups (the unemployed, women, young people and people living in rural areas) into the mainstream economy (Business Trust, 2007).

\section{4}

\section{Tourism SMME research}

Until recently, the literature on tourism entrepreneurship and small enterprises in South Africa was undeveloped. The first work on SMMEs in the tourism sector was that produced by the Land and Agriculture Policy Centre (1995) which hosted a workshop to discuss specific issues involving small entrepreneurs in tourism. Other research that followed in the 1990s included that of Visser and Van Huyssteen $(1997,1999)$ who pioneered work on the guest house sector as a new phenomenon in South African tourism. As the national importance of promoting and upgrading SMMEs in tourism was raised, further more detailed research has been undertaken on several issues concerning SMME development in tourism (Bourgouin, 2002; Kirsten \& Rogerson, 2002; Rogerson, 2003; DTI, 2004a; Nuntsu et al., 2004; Rogerson, 2004a, 2004b, 2005a, 2005b; Saayman \& Olivier, 2005; Thomas, 2005; Bresler \& Popova, 2006). This body of recent independent and policylinked research on SMMEs in tourism underlines the critical value for policy development of conducting sector-differentiated research on the SMME economy.

Although large companies drive and economically dominate the South African tourism industry, it remains the case that, as in most countries of the world, the vast majority of South African tourism enterprises fall into the category of SMMEs. As an economic sector, one of the most distinguishing features of tourism is the overwhelming pre-eminence of small-scale entrepreneurship. In South Africa, accurate data on the number of SMMEs in the local tourism economy is not available, particularly in respect of the emerging black-owned tourism enterprises, many of which are unregistered informal or micro-enterprises. One study in the Free State showed, however, that at least 97 per cent of formal enterprises in the province's travel and tour industry would be classed as SMMEs (Rogerson, 2005b). On a national level, the DTI recently calculated that "there are more than 50 000 tourism businesses in the economy" (DTI, 2005a: 28); and, on the basis of that estimate, the SMME tourism economy nationally must have at least 50000 enterprises. Within the category of tourism SMMEs must be recognised different sub-groups of businesses (Rogerson, 2005a). On the one hand are the groups of established, almost predominantly white-owned SMMEs that operate a host of different establishments from travel and touring companies, restaurants, small hotels, self-catering and resorts, game farms, bed and breakfasts or backpacking hostels. On the other hand are the emerging black-owned tourism economy which is a mix of formally registered micro-enterprises and informal tourism enterprises (DTI, 2004a). Some writers use the designation "second economy" enterprises to refer to this group of enterprises (Thomas, 2005; HSRC, 2006).

In terms of South African SMME development, one distinguishing feature of tourism is that it represents an important focal point for what is described as "lifestyle entrepreneurship" (Rogerson, 2005a). For lifestyle entrepreneurs, economic motives in running their businesses are matched by "non-economic", personal or environmental factors in encouraging the startup of tourism small businesses, particularly in the operation of bed and breakfast accommodation or small guest houses The importance of lifestyle motivations is apparent in findings concerning the motivations of many white entrepreneurs running guest houses and other small-scale forms of accommodation in the Western Cape, the Midlands of KwaZulu-Natal, Mpumalanga and Free State (Visser \& van Huyssteen, 1997, 1999; Mathfield, 2000; Marais, 2004; Rogerson 2005b; Bresler \& Popova, 2006; DTI, 2006b). 
By contrast to lifestyle entrepreneurs, there are other sub-groups of tourism SMME entrepreneurs functioning in South Africa. In common with the international experience there is an important group of both white and black tourism entrepreneurs who are driven by "opportunistic" or "growth" motivations for the development of tourism small businesses (DTI, 2006b). Nevertheless, one must also recognize that the South African tourism SMME economy is populated by a growing number of "marginal" or "survivalist" entrepreneurs who operate tourism SMMEs with little prospect of substantial income or employment expansion (HSRC, 2006). The operations of many of the emergent travel and tour operators in areas such as Soweto, Alexandra or Khayelitsha (Nemasetoni, 2005; Nemasetoni and Rogerson, 2007) and even a significant number of township bed and breakfast operators whose occupancy levels are meagre (Rogerson, 2004c, 2004d; Thomas, 2005; Lourens, 2007), would fall under this categorisation.

Outside of urban areas, the general trend is shown to be the existence of a high proportion of survivalist tourism businesses operating especially in hospitality and related services (such as arts and crafts) by struggling entrepreneurs (HSRC, 2006). In an area such as the rural Wild Coast the vast majority of tourism entrepreneurs would be classed as "marginal" and run by necessity entrepreneurs who operate tourism businesses at bare levels of survival (Ndabeni, 2005). In examining the potential for community-based/routes tourism in South Africa ECI Africa (2006a, 2006b) identify the category of a marginalised community-based tourism enterprise or MCBTE which is "one that does not fall within the mainstream economy and is run by the poorest of the poor" (ECI Africa, 2006a: 1). It is argued that "improving the conditions of MCBTEs can be viewed as a development challenge" (ECI Africa, 2006a: 6). The advancement of communitybased tourism is viewed as a channel to create opportunities for historically disadvantaged enterprises wishing to enter the tourism economy. CBT offers opportunities to MCBTEs and bring development to areas that offer limited economic potential in other areas (ECI
Africa, 2006a, 2006b). The development of CBT routes can thus "facilitate the geographic spread of travellers by encouraging them to go 'off the beaten track"' (ECI Africa, 2006b: iii). It is stressed that given appropriate support through route development and promotion, MCBTE "can make inroads into the tourism mainstream" (ECI Africa, 2006b: ii).

Of critical policy relevance are research findings that show the advantages enjoyed by the more established tourism entrepreneurs as compared to the constraints that confront emerging tourism entrepreneurs. In particular, it has been shown that established SMME entrepreneurs have an advantage in terms of access to finance (Saayman \& Olivier, 2005; Lourens, 2007). Often the tourism SMME is linked to alternative sources of income to farming (agro-tourism or farm tourism) or other income generating activities (Mathfield, 2000). In the case of retirement "lifestyle entrepreneurs" these are often especially well-capitalised businesses through the asset base of the entrepreneur. In addition to economic capital, commonly these established entrepreneurs enjoy high levels of social capital in terms of access to marketing networks, sources of information and data to support their tourism business. In addition, the high levels of social capital are enhanced by the high levels of education of these entrepreneurs which result in high levels of managerial skill (Saayman \& Olivier, 2005; Lourens, 2007). Finally, there are advantages for established entrepreneurs in terms of their cultural capital as represented by their language proficiencies for dealing with different types of tourists (both domestic and international), general awareness of the tourism market (albeit not always acquired through formal training) and sound acquired knowledge of the "tastes" and "experiences" that are generally sought out by large segments of the tourism market (DTI, 2004a). To a large extent, the dominance by mainly white-owned SMMEs of the accommodation and travel and tour operator segments of the tourism sector in South Africa can be understood in terms of the above set of advantages (see Visser \& Van Huyssteen, 1997, 1999; DTI, 2004a).

Different sets of growth constraints impinge upon the development of different kinds of 
tourism SMMEs. In particular, there are certain differences between the growth constraints that affect established as opposed to emerging SMMEs in tourism. For established (mainly but not exclusively white) entrepreneurs the key issues relate to the volume and quality of local, provincial and international marketing of tourism products (DTI, 2004b; Rogerson, 2005a; DTI, 2006b). Another key set of issues that is highlighted in particular in research undertaken by the SBP (2006a, 2006b) relates to the impact and burdens of regulations on tourism SMMEs. The most recent findings confirm the high regulatory costs born by tourism enterprises, issues of burdensome tax compliance requirements and of problems regarding municipal regulations, such as those relating to signage and zoning (SBP, 2006a). Overall, the SBP (2006a) research discloses red tape and costs of compliance as important barriers to the expansion of many tourism SMMEs. Nevertheless, in other research on small tourism entrepreneurs in the backpacking sector of tourism a different picture emerges (ECI Africa, 2006c). Here, it was disclosed that the absence of any municipal or provincial regulations specifically related to backpacker hostels (as opposed to bed and breakfasts or guest houses) was a significant blockage and problem for the development of this segment of tourism SMMEs in South Africa (ECI Africa, 2006c).

Other recent research shows that emerging SMMEs operate at a disadvantage with respect to both the enormous market power enjoyed by large tourism enterprises and to the advantages of economic, social and cultural capital of established SMMEs (Nemasetoni and Rogerson, 2007). The competition offered by established tourism businesses - both large and small - clearly functions as a massive constraint on the development of emerging businesses. This is best illustrated by research findings on emerging entrepreneurs in the travel and tour industry of Gauteng. Nemasetoni's (2005) interviews with 40 emerging travel and tour operators disclose the limits placed upon the growth of these enterprises by the dominance of large and established SMMEs in the travel and tour sector. In rural areas, opportunities for successful tourism entrepreneurship are reduced severely by infrastructural deficiencies for tourism development and skills shortages, so that much of the emerging rural tourism entrepreneurship operates at bare survival levels and approximates a situation of "forced" or necessity entrepreneurship (Ndabeni, 2005). In a useful contribution Bourgouin (2002) examines the potential use of new ICT technologies for overcoming certain of the constraints that confront rural tourism enterprises.

In terms of understanding the problems facing emerging urban SMME entrepreneurs, the most detailed material currently comes from recent studies that have looked at problems facing emerging tourism SMMEs in the accommodation sub-sector, which is currently one of the priority targets for government transformation policies (Rogerson, 2004b). The findings on emerging black-owned smallscale accommodation establishments, show that they are largely confined spatially to the apartheid-designated spaces of townships, with the largest clusters found in Soweto, Khayelitsha and Inanda (Rogerson, 2004d; Lourens, 2007). This distinctive geography offers opportunities but at the same time imposes considerable limits upon the growth of these establishments. The emerging SMMEs are confined by geography to the specialized niche of "township tourism" and thus do not attract the wider mix of business as well as leisure tourists that visit the parallel accommodation establishments as operated by established SMME entrepreneurs (Lourens, 2007). This points to a need to diversify the range of tourism product offerings in these areas (TEP, 2006a).

Lifestyle entrepreneurship is not a feature of the emerging SMME economy, in which economic motives for business operation are paramount (DTI, 2006b). Education levels of many emerging tourism SMME entrepreneurs are relatively high with many entrepreneurs having tertiary qualifications, with several former nurses and teachers amongst the ranks of new tourism entrepreneurs. Unlike the situation observed among rural tourism entrepreneurs in the Wild Coast (Ndabeni, 2005), the majority of urban tourism SMMEs have been launched as a result of perceived 
market opportunities rather than as a result of a desperate search for survivalist incomes due to unemployment or retrenchment. The largest element of entrepreneurs would be classed as "opportunistic" in the sense of initiating their businesses in response to perceived market opportunities and an observed increased flow of visitors to townships (Rogerson, 2004d).

The major constraint that was identified for their business development, was the need to improve the marketing of their businesses individually, and collectively the marketing of townships as new and diversified spaces for tourism. Marketing is a broad umbrella term and covers at least two different issues (Lourens, 2007). First, there is a need for greater knowledge of and exposure to new market trends. The tourism marketing process and how it is evolving, needs to made known particularly in terms of information technology and marketing through the internet. Second, market research needs to be better understood by SMME entrepreneurs and especially of the need to develop marketing tools and techniques. SMMEs need access to accurate and recent market information in order to do their own assessments. The need for financial assistance to assist with the upgrading of accommodation facilities, particularly in response to the demands of discerning international tourists is another important growth constraint (DTI, 2006b). Unlike the position of established SMMEs, who finance upgrading of their premises from retained earnings, this capacity for financing extensions currently does not exist for most emerging SMMEs (Rogerson, 2004e). Another key problem for emerging entrepreneurs is that of access to channels of information about market opportunities, including those related to the 2010 FIFA World Cup (Grundlingh, 2006). Moreover, small tourism entrepreneurs suffer from the lack "of an integrated powerful national information platform to offer access to the latest available tourism products" (Grundlingh, 2006: 29). Overall, it is shown that whilst emerging entrepreneurs are entering the tourism industry in increasing numbers, especially in activities such as B \& Bs where barriers to entry are relatively low, they continue to face sets of "significant barriers to sustained growth" (Monitor, 2004: 46).
In terms of market access, it has been pointed out that the leisure tourism channel in developing countries, including South Africa, "is usually very small and is dominated by experienced businesses with strong ties in particular source markets" (Lourens, 2007: 18). Overall, SMMEs are unsophisticated in terms of their business operations and lack the necessary formal systems which are often required to do business with larger enterprises. Indeed, for large businesses there is usually no interest or incentive to do business with SMMEs. The only occasions on which large firm-small firm relationships are developed are through government leveraging or market pressures.

Small accommodation providers are generally excluded from the package tour market and instead are reliant on a strong independent travel market (Lourens, 2007). Accordingly, considerable attention is currently focused on the issues around ICT (information and communication technologies) development and infrastructure. In November 2006 the International Finance Corporation PEP Africa launched the SMME Market Access to Regional Tourism (SMART) programme which aims to strengthen "the marketing capacity of small hotels, guesthouses and local tour operators across Africa" (IFC, 2007). In particular, small entrepreneurs in tourism are brought on line through the WorldHotel-link.com reservation platform which creates direct contact with independent travellers, one of the largest and fastest growth segments of the international travel market. The programme is being piloted in several African countries, including South Africa with a focus on Greater Johannesburg/Soweto, which was selected to be the first online portal (Lourens, 2007). The two key elements of the programme are thus to create market access for SME accommodation and other SME tourism product providers using an e-marketing place; and to enhance the skills base of participating SMEs (Lourens, 2007: 3). Overall, whilst most SMMEs are acutely aware of the potential for ICT development to improve their business "very few have access to the right infrastructure, especially referring to problems associated with slow and/or expensive internet access and the lack of good service providers in rural areas" (Lourens, 2007: 20). 


\section{5}

\section{Current research on creative industries}

Since the first landmark recognition by the Cultural Strategy Group (1998a) of the potential significance of "creative industries" in the late 1990 s, a much wider range of investigations on this sector has appeared in South Africa, compared to BPO\&O. The array of available work includes independent academic studies as well as government commissioned research. The most important research is that produced by Create SA (2003) at national level by Newton (2003) for Johannesburg, the Gauteng Province (2005) study, and works by van Graan (2005a, $2005 b$ ) in the Western Cape. Of significance is also the unpacking of "creative industries" and the undertaking of certain more focussed investigations into leading segments of creative industries in South Africa. Among the segments that have received specific attention are crafts (Kaiser Associates, 2005a, 2005b), film (Tuomi, 2005, 2006), and fashion (Rogerson, 2006). A landmark study is the appearance in 2007 of the customised sector development strategy for craft (Department of Trade and Industry, 2007)

The series of research reports produced by the Cultural Strategy Group are highly relevant for understanding the creative industries, including SMME development. The core objective of the Cultural Industries Growth Strategy (CIGS) was of "integrating arts and culture into all aspects of socio-economic development" in South Africa (Newton, 2003: 25). The Cultural Strategy Group produced detailed reports and recommendations for supporting craft (Cultural Strategy Group, 1998b), film and video (Cultural Strategy Group, 1998c), music (Cultural Strategy Group, 1998d), and publishing industries (Cultural Strategy Group, 1998e). Although precise numbers are unavailable due to the poor quality of statistics on the sector (Gauteng Province, 2005: 9), the vast majority of enterprises involved in these cultural/creative industries would be categorised as SMMEs. Overall, the 'Creative South Africa' initiative sought to introduce and demarcate "cultural industries as an important sector in its own right" (Cultural Strategy Group, 1998a: 7) in terms of national policy debates.
The subsequent Creative Industries Sector scoping study undertaken for the City of Johannesburg, built on foundations laid by the national cultural industry study (Newton, 2003). The results of this research provided the basis for the Gauteng provincial framework for creative industries (Gauteng Province, 2005). Essentially, the definitions used by the Cultural Strategy Group (1998a) were applied to re-name the sector as "creative industries" (Newton, 2003). The focus of the scoping investigation was primarily upon the segments of TV and film, music, performing arts, visual arts, crafts, and design. The research highlighted that the "Johannesburg creative industries sector dominates the national profile" (Newton, 2003: 42) and that the sub-sectors that dominate the local landscape are "craft, performing arts, visual arts, music and film" (Newton, 2003: 47).

In common with the emerging national picture of cultural industries, it was demonstrated that the sector of creative industries in Gauteng is "characterized by a high level of small and micro-enterprises, the sole proprietors of which are predominantly the producers of creative products or content" (Gauteng Province, 2005: $8)$. In the majority of cases, particularly in micro-enterprise, the proprietor fulfils a set of multi-tasking roles as producer, agent, marketer and retailer (Newton, 2003). The products of the Johannesburg creative industries economy are overwhelmingly targeted at local markets. Indeed, the majority of products and services are consumed within the creative sector itself. None the less, mirroring the strategic position of creative industries in the value chains of other sectors, it was recorded that "the major private sector markets for creative industry products are the tourism, services and retail sectors" (Newton, 2003: 51).

The creative industries sector was found to exhibit signs of growth in terms of new business start-ups and by a profile of enterprises that was dominated by business start-ups occurring particularly post-2000 (Newton, 2003: 44). A significant finding across creative industries as a whole was that their estimated annual turnover figure of R50 000 indicates that the sector contains a large element of "survivalist" enterprises. The survey of creative industries 
in Johannesburg disclosed that 51 per cent of enterprises reported they worked across between 2 to 5 of the different spectrum of activities that comprise the "sector" of creative industries (Newton, 2003). It was also shown that creative industries exhibited a locational tendency towards geographical clustering. Natural agglomerations and clusters are emerging in the "entertainment-based" sub-sectors such as music, film, television and the performing arts on the one hand and "arts and design-based" sub-sectors such as design, crafts and the visual arts on the other (Gauteng Province, 2005: 8).

Another finding is that whilst the cultural sector (especially performing arts and dance) is relatively unstable, due to its heavy dependence on government subsidies, this is not necessarily the case for the creative industries (like music, fashion, film and video) "which are able to operate on business principles and generate income" (Gauteng Province, 2005: 8). Finally, whilst white-ownership was strong in the "commanding heights" of the sector - in terms of the largest and dominant enterprises - it was observed in Johannesburg, black economic empowerment was advancing in creative industries.

Similar findings to those from Gauteng research have been reported by two recent investigations produced for the Western Cape Provincial Government (Van Graan, 2005a, 2005b) and by a national study (Create SA, 2003). In the research conducted by van Graan (2005a) the key characteristics of creative industries in the Western Cape were found to be as follows: predominantly small and micro-enterprises employing less than 50 people are labour-intensive have high levels of differentiation of income with almost as many part-time employees as full-time staff and comprise both a non-profit and for profit sectors. The are inclined to have low income levels; direct links to but also impact indirectly upon the tourism and retail sectors; and, provide employment as well as management opportunities for women.

On the national scale, Create SA, an organisation established to promote skills training in creative industries, issued a report based upon responses obtained from 1059 enterprises or organisations across creative industries (Create SA, 2003). The most significant findings from this investigation were threefold. First, enterprises in the sector are largely selfsustaining, albeit government and international grant funding does play a role in developing the sector. Second, the results confirm that revenue across the sector is low and in most cases at a survivalist level. Three, major markets for creative industry products are the tourism, services and retail sectors. Most products are consumed at local and provincial level. Only 21 per cent of enterprises distributed products and services at national level and 11 per cent into international markets, reflecting both an untapped market potential and absence of skills and resources in marketing and distributing products nationally and internationally (Create SA, 2003).

Finally, further information is available for creative industries in a set of investigations that focus upon issues relating to particular segments of creative industries rather than the development of creative industries as a whole. The Western Cape research by Van Graan (2005a) provides useful baseline information across various segments of creative industries in the province and extends the information provided in the Cultural Strategy Group (1998a) research. Two recent papers by Tuomi $(2005,2006)$ unpack issues relating to the South African film sector, an industry recognised to be of considerable significance, albeit the focus of little independent research. The film industry is shown to be characterised by high levels of horizontal and vertical integration which results in concentration of ownership and raised entry barriers for new players. Although the industry is dominated by large enterprises, such as Primedia, Johnnic Communications and Sasani, Tuomi (2006) shows the role played by SMMEs in various parts of the value chain. The South African fashion industry also has been the focus of some recent research in Johannesburg (Rogerson, 2006). Of particular interest are the problems facing young designers in upgrading their design enterprises in the city's fashion district and of the need to synergise developments taking place in fashion with those in tourism (Gatawa, 2006). 
In terms of the several segments of creative industries, research on the craft sector is of particular significance because, as the Tourism Enterprise Programme (TEP) (2006a: 38) argues, the craft industry represents "a potentially powerful means of providing job opportunities to the thousands of previously disadvantaged and marginalised people, the majority of which are women". Nationally, the craft sector is shown as overwhelmingly dominated by small, microor informal enterprise (Ndabeni, 2002; Kaiser Associates, 2005a; Ndabeni, 2005) The TEP's (2006b) own research identifies arts and crafts as critical for extending the benefits of SMME support programmes to Second Economy communities, especially in rural South Africa.

In rural areas several small localised studies have been conducted around issues relating to the problems faced by handicraft producers (Ndabebi, 2002; Shackleton, 2004; Shackleton and Shackleton, 2004; Shackleton and Steenkamp, 2004; Pereira et al., 2006). These studies point out the challenges of access to shrinking natural resources, to market channels and of the constraints of limited or inadequate training and education (Rogerson \& Sithole, 2001; Ndabeni, 2005). Shackleton et al. (2007: 698) stress that "local markets tend to be relatively poorly acknowledged, underappreciated and often neglected" as most attention concentrates on products procured for outside or export markets. Indeed, the core policy message of this section is that, as Pereira et al. (2006: 478) argue, "Local-level trade in these products remains undervalued by most governmental policy makers. As a result, institutional support for these activities is lacking". Following Shackleton et al. (2007: 700 ), the term "local" here refers "to encompass immediate village markets, markets within neighbouring villages and local towns, roadside, harbour or junction selling points, and markets in the nearest large urban centres and cities". An important dimension of "local" markets is pension markets, which are a focal point for craft producer traders (Shackleton \& Shackleton, 2004; Shackleton, 2005).

As the policy significance of craft has been recognised more widely, a number of much larger national or provincially focused investigations have been undertaken. The objective of these studies has been to inform sector development support interventions for the craft industry (DTI 2004b; Elk, 2005; Kaiser Associates, 2005a, 2005b; DTI, 2007). It is significant that these recent studies reinforce the importance of the craft industry not only for marginalised rural areas but also for urban communities. Indeed, in terms of the craft sector and the craft value chain, urban centres like Johannesburg and Cape Town clearly are critical centres for this industry (Newton, 2003; Gauteng Province, 2005; Kaiser Associates, 2005b).

The craft sector is defined increasingly in terms of the creation and production of goods on a small-scale basis and using hand processes (DTI, 2007: 11). The craft value chain includes design, provision of inputs, production, services and distribution, retail and consumption. The study by Kaiser Associates (2005a: 1) asserts that "value chain relations in the sector tend to be complex and contested, as producers do not necessarily have the skills to manage nonproduction activities such as distribution and marketing; intermediaries are often necessary, but resented, with perceptions of inappropriate distribution of margins". Materials, specific techniques and product types vary significantly resulting in great diversity in the sector. In addition, it is revealed that craft products may have different quality standards and scales of production as well as be positioned differently within markets (Elk, 2005). From Western Cape research it is disclosed that market positioning includes predominantly functional items, fashion-led items, gift and novelty items, corporate gifts, collectibles or Craft Art, souvenirs and socially responsible or fair trade items (Kaiser Associates, 2005a, 2005b). Among the constraints that challenge the upgrading and competitiveness of enterprises in the craft sector, the existing research highlights, inter alia, inadequate information on the sector, inadequate linkages with design skills, a tendency for production of certain crafts to be supply- rather than demand-driven, lack of reliability of producers on quality/time criteria, inadequate access to raw materials and finance; weak business skills of entrepreneurs; inadequate alignment of SMME support 
services to the craft sector and of the inadequate outreach of interventions into marginalised and rural areas.

The above research identifies the core problems facing the upgrading of SMMEs in creative industries. Key cross-cutting issues for enterprise growth were recognised as lack of adequate skills, difficulty of market access, and a lack of innovative product development. Of significance and demonstrated by the rich research produced on the segment of craft is that required strategic interventions must be customised and differentiated according to specific segments of creative industries. The sector development strategy for craft takes forward this theme and proposes a series of actions to address seven substantive problems which are identified: lack of coordination, information dissemination and a common vision for craft; lack of reliable national sector profile data; weak skills base in manufacturing enterprises which impacts upon product supply to markets; high and uncompetitive product pricing; lack of research and development; poor ability to capitalise on market opportunities; and, lack of a common marketing strategy. The sector development strategy identifies a number of key initiatives to be implemented in the next three years, including an enterprise development programme to assist established as well as emerging craft enterprises and the establishment of a set of regional urban hubs with strong links to prioritised rural hubs in order to promote and facilitate the craft trade (DTI, 2007).

\section{6}

\section{Concluding remarks}

In comparing the existing state of research in the three case study priority sectors, it is apparent immediately that there is unevenness in the volume of available material for understanding the position of SMMEs. The most outstanding finding is that during the last five years a distinctive body of research on SMMEs in tourism in South Africa has accumulated. Importantly, this sector-specific research on SMMEs in tourism complements other work which analyses opportunities and challenges that confront the tourism sector as a whole (eg. Monitor, 2004; DTI, 2005c). For the sector of creative industries an emerging set of work is beginning to disclose issues specific to the upgrading of SMME enterprises. By contrast, in the sector of BPO\&O there has so far been little dedicated work which examines the particular issues that confront SMMEs operating in this sector. Accordingly, the limited knowledge of SMMEs in this sector is based largely upon analyses conducted of the problems facing the sector as a whole.

Overall, it must be concluded therefore that considerable value can be added to sector development initiatives in South Africa by the undertaking of additional sector-differentiated SMME research to complement research which is focused on sector development as a whole. At present, SMME development is not integrated fully into research for DTI Customised Sector Development Programmes. Moreover, no regular monitoring is undertaken concerning issues of SMME development or of the impact of policy interventions on SMMEs in any of DTI's priority sectors. These are important research gaps that need to addressed in order to strengthen the initiatives for promoting SMME development in South Africa as a whole.

\section{References}

1 AUSTRALIAN GOVERNMENT CULTURE \& RECREATION (2006) Creative Industries Cluster Study, available at www.cultureandrecreation.gov.au

2 BENNER, C. (2006) “'South Africa on call': Information technology and labour market restructuring in South African call centres", Regional Studies, 40: 1025-1040.

3 BENNER, C.; LEWIS, C. \& OMAR, R (2007) "The South African call centre industry: A study of strategy, human resource practices and performance", available at www.globalcallcenter.org

4 BOURGOUIN, F. (2002) "Information communication technologies and the potential for rural tourism SMME development: The case of the Wild Coast", Development Southern Africa, 19: 191-212.

5 BRESLER, N.C. \& POPOVA, M. (2006) "Guest house entrepreneurs exploit opportunities", in J.P. Grundling and L. Steynberg (eds.) $4^{\text {th }}$ International Conference on Entrepreneurship and Innovation, Tshwane University of Technology: Pretoria, 105-115. 
6 BUSINESS TRUST (2007) Annual Report 2006, Business Trust: Johannesburg.

7 CREATE SA (2003) National Skills and Resources Audit, Create SA: Johannesburg.

8 CULTURAL STRATEGY GROUP (1998a) "Creative South Africa: A strategy for realising the potential of the cultural industries", Unpublished report for the Department of Arts, Culture, Science and Technology, Pretoria.

9 CULTURAL STRATEGY GROUP (1998b) "Cultural industries growth strategy: the South African craft industry report", Unpublished report for the Department of Arts, Culture, Science and Technology, Pretoria.

10 CULTURAL STRATEGY GROUP (1998c) "Cultural industries growth strategy: The South African film sector report”, Unpublished report for the Department of Arts, Culture, Science and Technology, Pretoria.

11 CULTURAL STRATEGY GROUP (1998d) "Cultural industries growth strategy: The South African music sector report", Unpublished report for the Department of Arts, Culture, Science and Technology, Pretoria.

12 CULTURAL STRATEGY GROUP (1998e) "Cultural industries growth strategy: The South African publishing sector report", Unpublished report for the Department of Arts, Culture, Science and Technology, Pretoria.

13 DEPARTMENT OF CULTURE, MEDIA \& SPORT, UK (1998) Mapping the Creative Industries, available at www.culture.gov.uk/creative/creative_ industries.html

14 DTI (2004a) Annual Review of Small Business in South Africa - 2003, Enterprise Development Unit, DTI: Pretoria.

15 DTI (2004b) Draft customised sector development programme for the crafts sector, DTI: Pretoria.

16 DTI (2005a) A Growing Economy that Benefits All: Accelerated \& Shared Growth Initiative for South Africa (ASGI-SA): Discussion Document, DTI: Pretoria.

17 DTI (2005b) Business Process Outsourcing and Offshoring: Sector Development Strategy, DTI: Pretoria.

18 DTI (2005c) Tourism Sector Development Strategy, Trade and Investment South Africa for DTI: Pretoria

19 DTI (2006a) A National Industrial Policy Framework, Enterprise Industry Development Division, DTI: Pretoria.

20 DTI (2006b) Annual Review of Small Business in South Africa - 2004: A Qualitative Review, Enterprise Development Unit, DTI: Pretoria.
21 DTI (2007) Craft Sector Development Strategy, DTI: Pretoria.

22 ECI AFRICA (2006a) "Community/routes tourism sector study: Growth strategy”, Report prepared for FRIDGE, Trade and Industry Chamber, Johannesburg.

23 ECI AFRICA (2006b) "Community/routes tourism sector study: Executive summary”, Report prepared for FRIDGE, Trade and Industry Chamber, Johannesburg.

24 ECI AFRICA (2006c) "Backpacker tourism sector study", Report prepared for FRIDGE, Trade and Industry Chamber, Johannesburg.

25 ELK, E. (2005) "The South African craft sector", Report prepared for the Human Sciences Research Council, Pretoria.

26 GATAWA, N.G. (2006) "The emerging role of the fashion industry in Johannesburg's tourism development strategy", Unpublished Masters in Tourism Research Report, University of the Witwatersrand, Johannesburg.

27 GAUTENG PROVINCE (2005) Creative Industries Development Framework of the Gauteng Provincial Government, Department of Sport, Arts, Culture and Recreation: Johannesburg.

28 GRUNDLINGH, L. (2006) "Tourism in 2010", Discourse, 34 (2): 26-32.

29 HSRC (2006) "A Study of the 'Tourism second economy", Unpublished Report prepared for the Department of Environmental Affairs and Tourism.

30 INTERNATIONAL FINANCE CORPORATION (2007) "Building sector \& firm competitiveness", available at www.ifc.org

31 KAISER ASSOCIATES (2005a) "Craft first paper: The scope of the craft industry in the Western Cape", Input Paper prepared for the Western Cape Micro-Economic Development Strategy.

32 KAISER ASSOCIATES (2005b) "Craft second paper: Policy recommendations and interventions", Input Paper prepared for the Western Cape MicroEconomic Development Strategy.

33 KENNEDY, K. (2004) "Creating employment and economic wealth through developing the $\mathrm{BPO} \& \mathrm{O}$ sector", Paper prepared for The Presidency/ ComMark Sector Workshop.

34 KIRSTEN, M. \& ROGERSON, C.M. (2002) "Tourism, business linkages and small enterprise development in South Africa”, Development Southern Africa, 19: 29-59.

35 LAPC (1995) Tourism Workshop Proceedings - Small, Medium and Micro Enterprises, Working Paper 21, Land and Agriculture Policy Centre: Johannesburg. 
36 LOURENS, M. (2007) "Report: PEP Africa smart programme: Programme design and implementation", Unpublished report Tourism Intelligence, Pretoria.

37 MARAIS, L. (2004) "From small town to tourism mecca: The Clarens fairy tale". In C.M. Rogerson and G. Visser (eds.) Tourism and Development Issues in Contemporary South Africa, Africa Institute of South Africa: Pretoria, 420-435.

38 MATHFIELD, D. (2000) "Impacts of accommodation and craft-based tourism on local economic development: The case of the Midlands Meander", Unpublished Masters dissertation, University of Natal, Durban.

39 MCKINSEY \& COMPANY (2005) South Africa Calling: South Africa's Business Process Outsourcing \& Offshoring Opportunity, South Africa Foundation: Johannesburg.

40 MITIAL RESEARCH (2002) South Africa 2002/3: Call Centre Country Report, Mitial Research: Chester.

41 MONITOR (2004) Global Competitiveness Project: Summary of Key Findings of Phase 1, South African Tourism: Johannesburg.

42 NAIDOO, R. \& NEVILLE, M. (2005) "Call centres/business process outsourcing (BPOs): First paper" Input Paper prepared for the Western Cape Micro-Economic Development Strategy.

43 NDABENI, L. (2002) "Forest-product SMMEs in the Wild Coast spatial development initiative", South African Geographical Journal, 83: 159-166.

44 NDABENI, L. (2005) "Rural small enterprise development in the Eastern Cape: The constraints and development issues of forest-products and tourism SMMEs in the Wild Coast Corridor", Unpublished $\mathrm{PhD}$ dissertation, University of the Witwatersrand, Johannesburg.

45 NEMASETONI, I. (2005) "Contribution of tourism towards the development of black-owned small, medium and micro-enterprises (SMMEs) in post-apartheid South Africa: An evaluation of tour operators”, Unpublished MA Research Report, University of the Witwatersrand, Johannesburg.

46 NEMASETONI, I. \& ROGERSON, C.M. (2007)

"Township tourism in Africa: Emerging tour operators in Gauteng, South Africa”, in C.M. Rogerson and G. Visser (eds.) Urban Tourism in the Developing World: The South African Experience, Transaction Publishers: New Brunswick, NJ.: 205220.

47 NEWTON, M. (2003) "Joburg creative industries sector scoping report”, Unpublished Report for the Economic Development Department, City of Johannesburg,
48 NEW ZEALAND TRADE \& ENTERPRISE

(2005) "Creative industries sector engagement strategy", available at www.nzte.govt.nz.

49 NUNTSU, N.; TASSIOPOULOS, D. \& HAYDAM, N. (2004) "The bed and breakfast market of Buffalo City (BC), South Africa: Present status, constraints and success factors", Tourism Management, 25: 515-522.

50 PALADIN CONSULTING (2003) "International outsourcing market overview”, Unpublished report, Paladin Consulting, Johannesburg.

51 PALADIN CONSULTING \& CONSULTA RESEARCH (2004) "Research study into the BPO\&O/CC sector in South Africa", Unpublished report for TISA.

52 PEREIRA, T; SHACKLETON, C. \& SHACKLETON, S. (2006) "Trade in reed-based craft products in rural villages in the Eastern Cape, South Africa”, Development Southern Africa, 23: 477-495.

53 ROGERSON, C.M. (2003) "Tourism and transformation: Small enterprise development in South Africa", Africa Insight, 33 (1/2): 108-115.

54 ROGERSON, C.M. (2004a) "Tourism, small firm development and empowerment in post-apartheid South Africa". In R. Thomas (ed.) Small Firms in Tourism: International Perspectives, Elsevier: Amsterdam: 13-33.

55 ROGERSON, C.M. (2004b) "Black economic empowerment in South African tourism”. In C.M. Rogerson and G. Visser (eds.) Tourism and Development Issues in Contemporary South Africa, Africa Institute of South Africa, Pretoria: 321-334.

56 ROGERSON, C.M. (2004c) "Transforming the South African tourism industry: The emerging black-owned bed and breakfast economy", GeoJournal, 60: 273-281.

57 ROGERSON, C.M. (2004d) "Urban tourism and small tourism enterprise development in Johannesburg: The case of township tourism", GeoJournal, 60: 249-257.

58 ROGERSON, C.M. (2004e) "Financing tourism SMMEs in South Africa: A supply-side analysis". In C.M. Rogerson and G. Visser (eds.) Tourism and Development Issues in Contemporary South Africa, Africa Institute of South Africa, Pretoria, 222-267.

59 ROGERSON, C.M. (2005a) "Unpacking tourism SMMEs in South Africa: Structure, support needs and policy response", Development Southern Africa, 22: 623-642.

60 ROGERSON, C.M. (2005b) "Supporting tourism SMMEs in peripheral areas: The example of Free State Province", Acta Academica Supplementum, 4: 85-116. 
61 ROGERSON, C.M. (2006) "Developing the fashion industry in Africa: The case of Johannesburg”, Urban Forum, 17: 215-240.

62 ROGERSON, C.M. \& SITHOLE, P.M. (2001) "Rural handicraft production in Mpumalanga, South Africa: Organization, problems and support needs", South African Geographical Journal, 83: 149-158.

63 SAAYMAN, M. \& OLIVIER, E. (2005) "An analysis of tourism SMEs in South Africa", South African Journal for Research in Sport, Physical Education and Recreation, 27: 117-126.

64 SBP (2006a) Counting the Cost of Red Tape for Tourism Businesses in South Africa, ComMark Trust: Johannesburg.

65 SBP (2006b) The Impacts of Sector-specific Policies and Regulations on the Growth of SMEs in Eight Sectors of the South African Economy, Working Paper 06/112, Development Policy Research Unit, University of Cape Town: Cape Town.

66 SHACKLETON, C. \& SHACKLETON, S.E. (2004) "The importance of non-timber forest products in rural livelihood security and as safety nets: A review of evidence from South Africa", South African Journal of Science, 100: 658-664.

67 SHACKLETON, S. (2004) "Livelihood benefits from the local level commercialization of savanna resources: A case study of the new and expanding trade in marula (Sclerocarya birrea) beer in Bushbuckridge, South Africa”, South African Journal of Science, 100: 651-657.

68 SHACKLETON, S. (2005) "The significance of the local trade in natural resource products for livelihoods and poverty alleviation in South Africa", Unpublished $\mathrm{PhD}$ thesis, Rhodes University, Grahamstown.

69 SHACKLETON, S. \& STEENKAMP, C. (2004)

"The woodcraft industry in the LimpopoMpumalanga lowveld”. In M. Lawes, H. Eeley, C.M. Shackleton and B.S. Geach (eds.) Indigenous Forests and Woodlands in South Africa: Policy, People and Practice, University of KwaZulu-Natal Press: Pietermaritzburg, 399-438.
70 SHACKLETON, S.; SHANLEY, P \& NDOYE, O. (2007) "Invisible but viable: Recognizing local markets for forest products", International Forestry Review, 9: 697-712.

71 THOMAS, W. (2005) "Second Economy" Paths into South African Tourism Business, Centre for Tourism Research in Africa, Cape Peninsula University of Technology, Research Report 1: Cape Town.

72 TOURISM ENTERPRISE PROGRAMME (2006a) Annual Report for Year 6, Tourism Enterprise Programme: Johannesburg.

73 TOURISM ENTERPRISE PROGRAMME (2006b) "Strategic initiatives", available at www.tep.co.za

74 TUOMI, K. (2005) "Film first paper: The scope of the film industry in the Western Cape", Input Paper prepared for the Western Cape MicroEconomic Development Strategy.

75 TUOMI, K. (2006) "Microeconomic development strategy for the South African film sector", Trade and Industry Monitor, 37: 153-177.

76 UPSTART BUSINESS STRATEGIES (2006) Integrated Strategy on the Promotion of Entrepreneurship and Small Business, DTI: Pretoria.

77 VAN GRAAN, M. (2005a) "Cultural industries, arts, culture and creative arts first paper: Towards an understanding of the current nature and scope of the creative industries in the Western Cape", Input Paper prepared for the Western Cape MicroEconomic Development Strategy.

78 VAN GRAAN, M. (2005b) "Cultural industries, arts, culture and creative arts second paper: Policy recommendations and interventions", Input Paper prepared for the Western Cape Micro-Economic Development Strategy.

79 VISSER, G. \& VAN HUYSSTEEN, K. (1997) "Guest houses - new option for tourists in the Western Cape Winelands", Acta Academica 29: 106-137.

80 VISSER, G. \& VAN HUYSSTEEN, K. (1999) "Guest houses: The emergence of a new tourist accommodation type in the South African tourism industry", Tourism and Hospitality Research, 1(2): $155-175$. 